\title{
The Evolving Microbiome from Pregnancy to Early Infancy: A Comprehensive Review
}

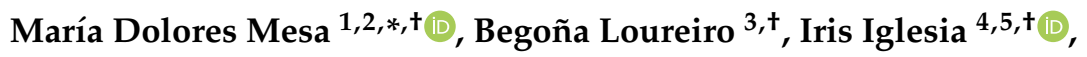 \\ Sergi Fernandez Gonzalez 6,7,+ , Elisa Llurba Olivé 8,9,10,+, Oscar García Algar 6,11,+(iD, \\ María José Solana ${ }^{12,+}, M^{a}$ Jesús Cabero Perez ${ }^{13,+}$, Talia Sainz $14,15,16,+\mathbb{D}$, \\ Leopoldo Martinez 15,17,+ , Diana Escuder-Vieco 18,+ , Anna Parra-Llorca 19, + , \\ María Sánchez-Campillo 20,+(D), Gerardo Rodriguez Martinez ${ }^{5,21,+}$, Dolores Gómez Roig ${ }^{6,7,+}$, \\ Myriam Perez Gruz 6,7,+, Vicente Andreu-Fernández 6,11, $+\mathbb{D}$, Jordi Clotet 6,11, ${ }^{\text {, }}$ \\ Sebastian Sailer $6,11,+$, Isabel Iglesias-Platas $6,7,22,+$, Jesús López-Herce ${ }^{12,+} \mathbb{D}$, Rosa Aras ${ }^{15,+}$, \\ Carmen Pallás-Alonso ${ }^{18,+}+\mathbb{D}$, Miguel Saenz de Pipaon ${ }^{23,+}\left(\mathbb{D}\right.$, Máximo Vento ${ }^{19,+}+\mathbb{D}_{\text {, }}$
}

María Gormaz ${ }^{19,+}$, Elvira Larqué Daza $20,+$, Cristina Calvo $14,15,16,24,+$ (D) and Fernando Cabañas $25,+$

1 Department of Biochemistry and Molecular Biology II, Institute of Nutrition and Food Technology “José

Mataix", Biomedical Research Center, University of Granada, Parque Tecnológico de la Salud,

Avenida del Conocimiento s/n, Armilla, 18100 Granada, Spain

2 ibs.GRANADA, Instituto de Investigación Biosanitaria, Complejo Hospitalario Universitario de Granada, 18014 Granada, Spain

3 Neonatology Unit, University Hospital Cruces, Biocruces Bizkaia Health Research Institute, 48903 Barakaldo, Spain; begona.loureirogonzalez@osakidetza.eus

4 Growth, Exercise, Nutrition and Development (GENUD) Research Group, Universidad de Zaragoza, 50009 Zaragoza, Spain; iglesia@unizar.es

5 Instituto de Investigación Sanitaria Aragón (IIS Aragón), 50009 Zaragoza, Spain; gerard@unizar.es

6 BCNatal-Barcelona Center for Maternal-Fetal and Neonatal Medicine (Hospital Sant Joan de Deu and Hospital Clínic), 08028 Barcelona, Spain; sfernandezgo@sjdhospitalbarcelona.org (S.F.G.);

ogarciaa@clinic.cat (O.G.A.); lgomezroig@hsjdbcn.org (D.G.R.); mperezc@sjdhospitalbarcelona.org (M.P.G.); viandreu@clinic.cat (V.A.-F.); jclotet@clinic.cat (J.C.); sebastiansailer34@gmail.com (S.S.);

iiglesias@sjdhospitalbarcelona.org (I.I.-P.)

7 Institut de Recerca Sant Joan de Déu (IR-SJD), 08028 Barcelona, Spain

8 Obstetrics and Gynecology Department, High Risk Unit, Sant Pau University Hospital, 08025 Barcelona, Spain; llurba@yahoo.es

9 Women and Perinatal Health Research Group, Biomedical Research Institute Sant Pau (IIB-Sant Pau), Sant Pau University Hospital, 08041 Barcelona, Spain

10 School of Medicine, Universitat Autònoma de Barcelona, 08193 Barcelona, Spain

11 Neonatology Unit, Hospital Clinic-Maternitat, ICGON, BCNatal, Gran Via de les Corts Catalanes, 585, 08007 Barcelona, Spain

12 Servicio de Cuidados Intensivos Pediátricos, Hospital General Universitario Gregorio Marañón, Departamento de Salud Pública y Materno infantil, Universidad Complutense de Madrid, 28040 Madrid, Spain; mjsolana@hotmail.com (M.J.S.); pielvi@hotmail.com (J.L.-H.)

13 Hospital Universitario Marqués de Valdecilla, Santander, 39008 Cantabria, Spain; mariajesuscabero@gmail.com

14 Servicio de Pediatría, Enfermedades Infecciosas y Tropicales, Hospital La Paz, 28046 Madrid, Spain; tsainzcosta@gmail.com (T.S.); ccalvorey@gmail.com (C.C.)

15 Instituto de Investigación Hospital la Paz (IdiPAZ), 28029 Madrid, Spain; leopoldo.martinez@salud.madrid.org (L.M.); rosa.aras@hotmail.com (R.A.)

16 Red de investigación Traslacional en Infectología Pediátrica (RITIP), 28046 Madrid, Spain

17 Servicio de Cirugía Pediátrica, Hospital La Paz, 28046 Madrid, Spain

18 Donated Milk Bank, Health Research Institute i + 12, University Hospital 12 de Octubre, Universidad Complutense, 28040 Madrid, Spain; diana.e.vieco@gmail.com (D.E.-V.); kpallas.hdoc@gmail.com (C.P.-A.)

19 Neonatal Research Group, Health Research Institute La Fe, University and Polytechnic Hospital La Fe, 46026 Valencia, Spain; annaparrallorca@gmail.com (A.P.-L.); Maximo.Vento@uv.es (M.V.); mgormi@yahoo.es (M.G.) 
20 Department of Physiology, Faculty of Biology, University of Murcia, 30100 Murcia, Spain; medit2011@gmail.com (M.S.-C.); elvirada@um.es (E.L.D.)

21 Department of Pediatrics, Faculty of Medicine, Hospital Clínico Universitario Lozano Blesa, 50009 Zaragoza, Spain

22 Neonatology Unit, Hospital Sant Joan de Déu, Institut de Recerca Sant Joan de Déu, BCNatal, 08028 Barcelona, Spain

23 Department of Neonatology La Paz University Hospital, 28046 Madrid, Spain; miguel.saenz@salud.madrid.org

24 European Network of Excellence for Pediatric Clinical Research, 27100 Bari, Italy

25 Department of Paediatrics-Neonatology Quironsalud, Madrid University Hospital and Biomedical Research Foundation-IDIPAZ, La Paz University Hospital, 28046 Madrid, Spain; fernando.cabanas@quironsalud.es

* Correspondence: mdmesa@ugr.es; Tel.: +34-958-246187

+ All the authors are the members of SAMID Network. RETICS funded by the PN I+D+I 2018-2021 (Spain), ISCIII-Sub-Directorate General for Research Assessment and Promotion and the European Regional Development Fund (FEDER), ref. RD16/0022.

Received: 28 November 2019; Accepted: 20 December 2019; Published: 2 January 2020

\begin{abstract}
Pregnancy induces a number of immunological, hormonal, and metabolic changes that are necessary for the mother to adapt her body to this new physiological situation. The microbiome of the mother, the placenta and the fetus influence the fetus growth and undoubtedly plays a major role in the adequate development of the newborn infant. Hence, the microbiome modulates the inflammatory mechanisms related to physiological and pathological processes that are involved in the perinatal progress through different mechanisms. The present review summarizes the actual knowledge related to physiological changes in the microbiota occurring in the mother, the fetus, and the child, both during neonatal period and beyond. In addition, we approach some specific pathological situations during the perinatal periods, as well as the influence of the type of delivery and feeding.
\end{abstract}

Keywords: microbiome; pregnancy; fetus; placenta; newborn; infancy; critical illness; sepsis; allergy

\title{
1. Introduction
}

Pregnancy induces a number of immunological, hormonal, and metabolic changes necessary for the normal development of the fetus and for a timely onset of labor and successful delivery [1]. It has been described that maternal microbiota influences prenatal and early postnatal offspring development and health outcomes $[2,3]$. There is a lack of consensus about the real nature of microbiome changes during pregnancy, since discrepant and unpredictable findings have been described [4-6]. These differences could be explained by the difference in gestational age, genetics, ethnicity, and environmental factors surrounding the participants included in those studies. Indeed, it has been described that maternal microbiota composition during pregnancy is related to maternal diet [7-9], and by pre-pregnancy weight and weight gain over the course of pregnancy [10-13]. Koren et al. described that the amounts of anti-inflammatory butyrate-producer commensal bacteria present in non-pregnant women gut microbiota decrease while bacteria associated with pro-inflammatory responses, such as Proteobacteria, increase during pregnancy [4]. Similarly, bacterial diversity tends to be reduced in vaginal microbiota during pregnancy while increasing vaginal Streptococci along with several specific Lactobacilli strains, which are thought to prevent the growth of pathogenic bacteria, as well as to help human digestion, and influence host innate and adaptive immune system responses [4,14]. Furthermore, the classical paradigm of the fetus as a sterile organism is under discussion, since a characteristic microbiome has been identified in the placenta, the amniotic fluid, and the fetus in healthy pregnancies $[15,16]$. However, this issue is under discussion. Perez-Muñoz et al. argued the weakness of evidence supporting the 
"in utero colonization hypothesis", due to methodological difficulties, and concluded that current scientific evidence does not support the existence of microbiome within the healthy fetal milieu [17].

Gut microbiota influences the immune function [18], and thus may modulate the response through different microbial-derived metabolites, especially short-chain fatty acids (SCFAs) such as butyrate, acetate, or propionate [19]. These are the key drivers of T-cell subset proliferation and activity $[19,20]$. Gastrointestinal bacteria generate SCFAs after fermentation of complex dietary carbohydrates. These metabolites may have an influence both in the mother and in the newborn by down-regulation of pro-inflammatory responses at the specific sites where the allergens are located, which typically precedes asthma in childhood [21]. In addition, the may also influence bone marrow stimulation by reprogramming the immunological tone of the mammalian ecosystem [22].

Finally, it is important to consider that the discrepancies of the data obtained to date could be influenced by a number of factors such as the dietary pattern, the ethnicity, the geographic location, and the research methodology. The limitations of classical culturable methods have been improved with new molecular methods used to characterize the microbiota. However, these new methods have their own limitations, as reagent, laboratory contamination, and the inability to differentiate living and dead microorganisms. Indeed, recent research complements the study of microbiome with metabolomics and proteomic analysis in order to complete the whole metabolic picture of the microbiota and its metabolic status. Therefore, further studies are needed to confirm the evolution of microbiota during pregnancy and its influence in healthy and complicated labors and the newborn [23].

The present review summarizes the actual knowledge related to changes in maternal and fetal microbiota occurring during pregnancy, which may influence the newborn and infant development. In addition, changes in specific pathological infancy situations have also been revised.

\section{Changes in the Microbiome during Pregnancy}

During pregnancy, the female body undergoes hormonal, metabolic, and immunological changes to preserve the health of both the mother and the offspring [1]. These changes alter the mother microbiota at different sites such as the gut, the vagina, and the oral cavity. However, published data are not consistent, since a number of factors might influence the microbiota profile such as the diet, antibiotic, or other supplement intakes, as well as the methodology of research. Therefore, a holistic approach is needed to understand all this information.

\subsection{Gut Microbiota}

The gut microbiota shifts substantially throughout the progression of the pregnancy and is characterized by reduced individual richness (alpha-diversity) (Figure 1), and increased inter-subject beta-diversity [4]. These changes are not related to, although they may be influenced by, the diet, antibiotic treatments, gestational diabetes, or pre-pregnancy body mass index, but are vital for a healthy pregnancy [4]. It has been suggested that other factors, such as the state of the host immune and endocrine systems, may actively contribute to the observed modifications [24]. During the first trimester, the gut microbiota pattern is similar in many aspects to that of healthy non-pregnant women, showing a predominance of Firmicutes, mainly Clostridiales, over Bacteroidetes [25]. Then, maternal gut microbiota declines in butyrate-producing bacteria, while Bifidobacteria, Proteobacteria, and lactic acid-producing bacteria increase from the first to the third trimester, when the microbiota resembles an unpredictably disease-associated dysbiosis that differs greatly among normal pregnancies [4]. Changes in the host immune system of the gastrointestinal mucosa together with metabolic hormonal changes may trigger a low-grade pro-inflammatory status that could facilitate an increased diffusion of glucose from the gut epithelium towards the lumen, and thus may induce weight gain while modifying the gut microbiota during normal pregnancies [26]. Indeed, changes in the microbiota may contribute to the evolution of this process. In addition, disruption of maternal gut microbiota during the third trimester [27] may affect host metabolism in order to provide an energy supply for the fetus $[4,26]$. Moreover, it has been reported that the gut microbiota during pregnancy is a critical 
determinant of offspring health $[13,28]$, and that potentially determines the development of atopy and autoimmune phenotypes in the offspring [28]. However, the relationship among the immune system, the gut microbiota, and metabolism in pregnancy is unclear, and more research is needed to stablish final conclusions.

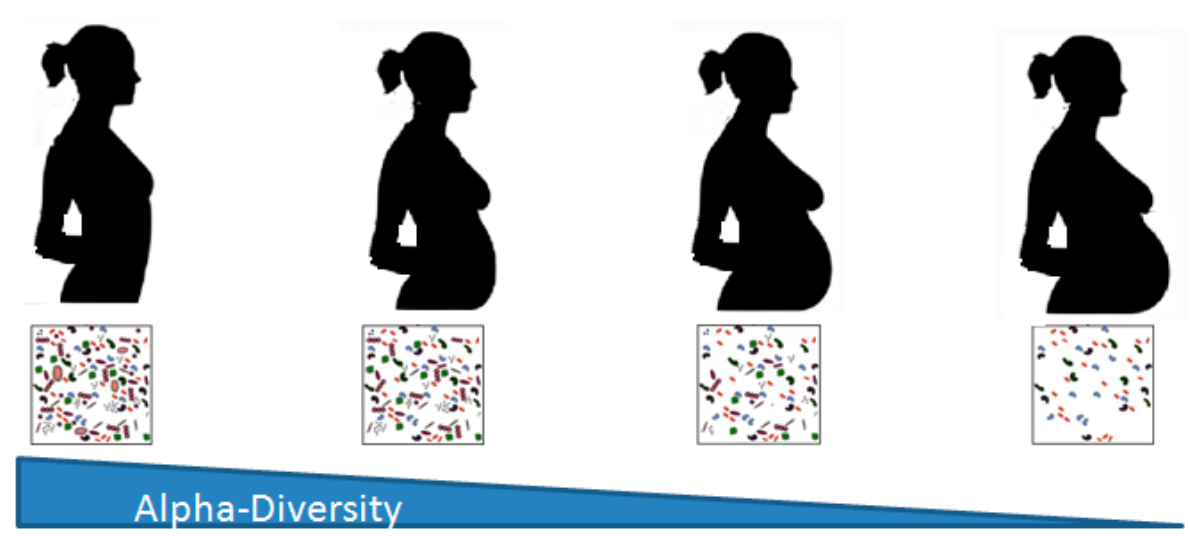

Figure 1. Alpha-diversity changes in gut microbiota during pregnancy.

\subsection{Vaginal Microbiota}

The composition of the vaginal microbiota is dynamic, corresponding with hormonal fluctuations throughout the woman's reproductive life, and also during pregnancy. A number of protective lactic acid-producing Lactobacillus species dominates the healthy vaginal microbiota in most reproductive-age women. These bacteria protect against vaginal dysbiosis and inhibit opportunistic infections through the direct and indirect protective effects of Lactobacillus products, such as lactic acid and bacteriocin among others. Lactic acid decreases vaginal $\mathrm{pH}$ and thus inhibits a broad range of infections [29], can directly affect host immune functions, by inhibiting pro-inflammatory responses, and also help to release mediators from vaginal epithelial cells and stimulate antiviral response [30]. In addition, Lactobacillus-derived bacteriocins may inhibit pathogen growth [31]. The degree of protection varies according to the predominant Lactobacillus specie [30]. Vaginal dysbiosis is comprised of a wide array of strict and facultative anaerobes that correlate to increased risk of infection, diseases, and poor reproductive and obstetric outcomes [32].

During normal pregnancy, the composition of the vaginal microbiota changes as a function of gestational age, with an increase in the relative abundance for Lactobacillus spp., such as L. crispatus, L. jensenii, L. gasserii, L. vaginalis, and a decrease in anaerobe or strict anaerobe microbial species, such as Atopobium, Prevotella, Sneathia, Gardenerella, Ruminococcaceae, Parvimonas, Mobilincus [33]. Those authors reported for the first time, that the composition and stability of the vaginal microbiota of normal pregnant women is different from that of non-pregnant women. In fact, low risk pregnant women have more stable vaginal flora throughout the pregnancy than non-pregnant women. Normal changes in the vaginal flora during pregnancy are transitions to another Lactobacillus community, and this stability would protect against ascending infections through the genital tract. In addition, they reported that Lactobacillus communities vary depending on the ethnicity of the women [33]. Stout et al. [34] confirmed that vaginal microbiota richness and diversity remained stable during the first and second trimesters of gestation in pregnancies ended at term, whereas in woman with preterm born, the richness and diversity decreased early in pregnancy. Therefore, early pregnancy may be an important environment, modulating preterm delivery. A meta-analysis reported significant diversity differences in vaginal microbiomes in the first trimester, between women with term and preterm outcomes, indicating a potential diagnostic utility of microbiome-related biomarkers [35]. In addition, the increase of pathogens in the vagina is associated with complications of pregnancy, in particular with an increased risk of preterm birth and spontaneous abortion [6]. 


\subsection{Oral Microbiota}

An increase in the microbial load in the oral cavity during pregnancy has been described. It has been hypothesized that pregnancy creates a nutrient environment that is more favorable to some sensitive strains [36]. The presence of pathogenic bacteria Porphyromonas gingivalis and Aggregatibacter actinomycotemcomitans in gingival sulcus were significantly higher during early and middle stages of pregnancy compared to non-pregnant women [37]. The oral alpha-diversity index was higher in the third trimester compared to non-pregnant women, and this may be related to the increase of progesterone and estradiol. [38]. One underlying mechanism refers to estrogens being substituted for vitamin $\mathrm{K}$ in bacterial anaerobic respiration, especially for black-pigmented Bacteroides such as Bacteroides melaninogenicus and Prevotella intermedia [38].

\subsection{Placental Microbiota and Fetal Colonization}

The classical paradigm of fetal environment as a sterile harbor has traditionally explained that microbes, and thus microbiome, are acquired both vertically (from the mother) and horizontally (from other humans or from the environment) during and after birth. However, recent data have questioned the traditional accepted dogma of human microbiome acquisition, proposing that neither the placenta, the amniotic fluid, nor the fetus are sterile.

Several findings using both culture and metagenomic techniques have suggested the presence of a low biomass microbial community in the healthy placenta [39-43]. The abundance of different species of Lactobacillus, Propionibacterium, and members of the Enterobacteriaceae family have been detected by DNA-based studies in placental tissue of pregnant women at term and it is under debate [16]. In addition, other authors have confirmed a distinct microbiota in both the placenta and amniotic fluid of healthy women at the time of elective C-section, characterized by low richness, low diversity, and the predominance of Proteobacteria [44]. Similarly, other studies have found microbes in amniotic fluid and umbilical cord blood in healthy asymptomatic women, as well as in those with pregnancy complications [45-47].

However, it is unclear where the fetal microbiota comes from, and when is the first fetal exposition. The presence of a different placental microbiota compared to the vagina raises the possibility that the infant may be first seeded in utero from other sources. Microorganism may pass through the placenta and colonize the fetus ascending from the vagina, from the oral cavity, from the urinary track, or from the intestinal lumen of the mother. These microorganisms may reach via the hematogenous route, the placenta, and then be transmitted to the fetus [48]. Some of those oral bacteria, such as Fusobacterium nucleatum, may be transmitted hematogenously during placentation by binding to the vascular endothelium, and modifying its permeability and the translation of other common commensals, such as Escherichia coli [49]. In addition, Franasiak et al. observed that Flavobacterium and Lactobacillus represent the majority of endometrial bacterium at the time of embryo transfer, supporting a new hypothesis of the endometrial environment participation [50].

Different studies have also detected microbiome in the first baby fecal sample, the meconium, supporting the in utero exposure to bacteria [51,52]. Staphylococcus has been reported as the most prevalent bacteria in meconium samples, followed by Enterobacteriaceae, Enterococcus, Lactobacillus, and Bifidobacterium even in infants born by C-section [52,53]. Modification in placental microbiota may be related with adverse pregnancy outcomes of pregnancy or symptoms of clinical infection [40].

On the contrary, Perez-Muñoz et al. [17] critically revised scientific evidence supporting both the "sterile womb" and "in utero colonization" hypotheses. These authors concluded that there is more evidence supporting a sterile womb environment. They suggest that methodological approaches, in which contamination is very easy at different steps and does not use appropriate controls, are responsible for the microorganism colonization described in utero. One well-controlled study compared oral, vaginal, and placenta samples with paired contamination controls. This study reported that when using molecular methods, placental samples were undistinguishable from their paired-contaminated samples. They concluded that while there were distinctive microbial signatures 
in oral and vaginal samples, they did not find a characteristic placental microbiota, evidencing a sterile environment [54]. Therefore, conclusions remain unachievable, and more studies are needed in this area.

\section{Changes in the Microbiome Related to the Type of Delivery}

There is great controversy in the scientific community about the relationship of the meconium and infant gut microbiota profile, and the type of delivery. Microbiome studies on early infancy have demonstrated a significant influence of the mode of delivery on the microbiome composition, suggesting the likely association of the infant gut bacteria with maternal vaginal or skin microbiome habitats. A systematic review has concluded that the diversity and colonization pattern of the gut microbiota were significantly associated to the mode of delivery during the first three months of life, which is a critical period of life for immunological programming [55]. However, the observed differences disappear after 6 months of infants' life, when solid foods are included in the diet [56]. It is important to clarify the influence of factors commonly accompanying C-section delivery on the microbiome, due to the potential influence on some non-communicable diseases, such as neonatal skin infection, asthma, allergies, obesity, inflammatory bowel disease, or type I diabetes mellitus [56,57].

Vaginally delivered newborn have shown bacterial communities resembling their own mother's vaginal microbiota, dominated by Lactobacillus, Prevotella, or Sneathia spp. In contrast, C-section-born infants harbored bacterial communities similar to those found on the skin surface niche, dominated by Staphylococcus, Corynebacterium, and Propionibacterium spp. [58] or potentially pathogenic microbial communities such as Klebsiella, Enterococcus, and Clostridium [57]. Other authors have reported that Bifidobacterium [59] and Bacteroides [55] seem to be significantly more frequent in vaginally compared with C-section delivered infants, which were mainly colonized by Clostridium and Lactobacillus [55]. The high abundance of Bifidobacterium species in infants is considered to promote the maturation of the healthy immune system, while high presence of Clostridium difficile is considered as one of the major intra-hospital hazards of severe gastrointestinal infections during infancy [55]. Another study proposed that some species of Propionibacterium were most abundant in the meconium of vaginally delivered Chinese infants, whereas C-section-born children had higher amounts of Bacillus licheniformis. In addition, the diversity of the microbial composition was also higher in vaginal than in C-section deliveries, although no correlation with maternal microbiome was reported [60]. Similarly, a metagenomic analysis found a Propionibacterium-enriched meconium in vaginal delivery mothers, which may proceed from skin or fecal microbes through direct contact during the natural labor [61]. Therefore, there is no consensus regarding the most colonizable pattern of the first microbiota community in the first three days after birth, although it seems that according to phyla, vaginal deliveries are more related to Actinobacteria and Bacteroidetes, while C-section deliveries are more related to Firmicutes. In addition, it has also been suggested that the transfer of maternal vaginal microbes plays a minor role in seeding infant stool microbiota since the overlap of maternal vaginal microbiota and infant faecal microbiota is minimal, while the similarity between maternal rectal microbiota and infant microbiota was more pronounced [62].

The discrepances of the results obtained could be due to different factors associated to C-section delivery such as antibiotic administration, but also to breastfeeding, maternal obesity, gestational diabetes mellitus, and even the analytical methodology. In addition, the diversity from Firmicutes and Bacteroides colonization levels on infants gut microbiota may be influenced by geographical variation such as the latitude [63].

Some authors have proposed that the lower presence of Bifidobacteria and Bacteroides, and the abundance of Clostridia and Lactobacillus, in infants delivered by C-section could be explained by perinatal antibiotics administration [55]. Mothers delivering by $\mathrm{C}$-section receive antibiotic prophylaxis before the beginning of surgery or, in some countries, after the cord clamping to minimize the direct exposure of the neonate to antibiotics [64]. In addition, Azad et al. determined that intrapartum antibiotics both in C-section and vaginal deliveries are associated with infant gut 
microbiota dysbiosis, although breastfeeding modifies some of these effects [65]. Nevertheless, Martinez et al. [66] performed antibiotic-free C-section delivery in mice and determined that these mice did not have the dynamic developmental gut microbiota changes observed in control natural born mice, evidencing the involvement of maternal vaginal bacteria in a proper metabolic development even in absence of antibiotics supporting the hypothesis of the antibiotic-modulated dysbiosis. It is worth to take into account that perinatal antibiotic administration may be associated with increased risk of developing morbidities such as asthma, allergies and obesity, which may be influenced by dysbiosis. In accordance, epidemiological data show that atopic diseases appear more often in infants born by C-section than after vaginal delivery $[67,68]$.

Furthermore, bacterial richness and diversity were lower in the infant gut of babies born after elective $\mathrm{C}$-section and higher in emergency $\mathrm{C}$-section, suggesting that colonization may be affected differently in both situations. It is important to highlight that emergency $\mathrm{C}$-section and vaginal delivery labor are frequently accompanied by rupture of fetal membranes, and exposing the fetus to maternal vaginal bacteria [65].

Importantly, C-section may decrease the colonization of milk-digested bacteria including the genus Lactobacillus in newborns during the first months of life [58]. In addition, the mode of delivery has a relevant impact on the microbiota composition of colostrums and milk [69,70], which also may be influenced by antibiotics administrated during C-section. It has been proposed that infants born by C-section lacked the early provision of breast milk essential to attain a proper gut microbiota that contains microbes such as Lactobacilli and Bifidobacteria. This could explain the higher colonization rates of these genera in vaginal compared to C-section-delivered infants [71]. In fact, Sakwinska et al. reported that only vaginal delivered and fully breastfed infants had gut microbiota dominated by Bifidobacteria [62].

Finally, there are several potential preventive intervention strategies to restore the gut microbiota after C-section [72]. The intervention could be focused on maternal administration of probiotics and prebiotics during gestation. There is a great interest about "seeding approaches" as "vaginal seeding" to reverse the effects of C-section delivery mode on the microbiome in early life, but at the same time there are critical voices concerned about safety and efficacy of this practice [56,72]. In addition, the intervention could concentrate on the neonate using "seeding" methods such as encouraging breastfeeding instead of formula feeding, or the use of infant enriched formulas. In this sense, supplementation with symbiotic, the combination of synergistic pre- and probiotics, might offer an innovative strategy to re-establish the delayed colonization of Bifidobacterium spp. in C-section-delivered children [73].

\section{Microbiome and the Type of Feeding}

Maternal diet establishes long-lasting effects on offspring gut microbial composition, which may have important clinical implications [74,75]. Complex interactions between breast milk cytokines and microbiota guide the microbiological, immunological, and metabolic programming of infants' health, which may explain the higher risk of obesity in infants with overweight and excessive weight gain mothers [76]. In addition, data supporting the notion of bacterial translocation from the maternal gut to extra-intestinal sites during pregnancy are emerging and potentially explain the presence of bacteria in breast milk [28].

Some authors have reported changes in meconium microbiota when delaying the collection of meconium samples by one day, supporting that the type of feeding or the environment has an influence after the birth, which may be more determinant to establish the intestinal microbiome during childhood [53]. Breast milk has been recognized as the gold standard for human nutrition [77]. The type of feeding has an important impact on gut microbial composition in preterm infants. In preterm infants, breast milk has been associated with improved growth and cognitive development [78] and a reduced risk of necrotizing enterocolitis and late sepsis onset $[76,79,80]$. Occasionally, the absence of mother's own milk (MOM) requires the use of donated human milk (DHM). A prospective cohort study has been launched to determine the impact of DHM upon preterm gut microbiota admitted in a neonatal intensive 
care unit. Despite the high variability of DHMs, no differences in microbial diversity and richness were found, although feeding type significantly influenced the preterm microbiota composition and predictive functional profiles. Inferred metagenomic analyses showed higher presence of Bifidobacterium in the MOM, a genus related to enrichment in the glycan biosynthesis and metabolism pathway, as well as an unclassified Enterobacteriaceae and lower unclassified Clostridiaceae compared with the DHM or in the formula fed groups. After adjusting for gender, postnatal age, weight, and gestational age, the diversity of gut microbiota increased over time and was constantly higher in infants fed their MOM relative to infants with other types of feeding. In addition, DHM favors an intestinal microbiome more similar to MOM despite the differences between MOM and DHM [81]. Preterm infants are prone to develop free radical-associated conditions [82] that may be influenced by the microbiota. In a recent study, urine oxidative stress biomarkers such as 8-hydroxy-deoxyguanosine (8OHdG/2dG), orto-tyrosine, and F2 isoprostanes, neuroprostanes, neurofurans, and di-homo-isoprostanes were longitudinally measured in preterm infants fed either MOM or DHM using validated mass spectrometry techniques. No significant differences for any of the markers studied were found between preterm babies fed MOM or DHM [83]. However, exfoliated epithelial intestinal cells transcriptome of preterm infants fed their MOM or a DHM induced a differential gene expression of specific genes which may contribute to a more efficient antioxidant response in the postnatal period [84]. Therefore, using DHM could have potential long-term benefits on intestinal functionality, the immune system, and metabolism [85-87]. However, available pasteurization methods cause changes that may blunt many of the positive aspects derived from the use of MOM [88-90]. Further studies are needed to understand the complex links between microbiome and breastfeeding, its impact on health programming, and to develop sensitive methods capable of providing human milk as similar as possible to their MOM, when the latter is not available.

\section{Microbiome in Pathological and Adverse Pregnancy Outcomes}

Some studies have compared the fetal and mother microbiome in relation to adverse outcomes such as prematurity or low birth-weight without reaching firm conclusions. Ardissone et al. [91] compared the meconium microbiome in newborn before and after 33 weeks of gestation and concluded that Enterococcus and Enterobacter negatively correlated with gestational age, and Lactobacillus and Phortorhabdus were more abundant in newborns with less than 33 weeks of gestation. They indicated that the composition of the microbiome may be involved in the inflammatory response that leads to premature birth more than the colonization alone. Specifically, preterm subjects with severe chorioamnionitis had higher abundance of Ureaplasma paroum, Fusobacterium nucleatum, and Streptococcus agalactiae [16]. The placental microbiome varies as a consequence of an excess of gestational weight gain, but is not related to obesity among women with spontaneous preterm birth. Indeed, this placental dysbiosis affects different bacterially encoded metabolic pathways that may be related to pregnancy outcomes [92]. Furthermore, it has been reported high abundance of Burkholderia, Actinomycetales, and Alphaproteobacteria in placental samples from gravidae delivered preterm, and of Streptococcus and Acinetobacter in placental samples from patients with a history of antepartum urinary infection. In contrast, Paenibacillus predominated in term placental specimens [15]. Other authors have proposed that the fetal intestinal microbiota derives from swallowed amniotic fluid, and that they may trigger an inflammatory response which leads to premature birth [91]. Considering that some Lactobacillus strains may possess potential anti-inflammatory activities, and could regulate blood glucose levels in diabetic humans [93], the low abundance of Lactobacillus in placentas of low birth weight neonates reported by Zheng et al. [94] might be related to a pro-inflammatory status in these pregnancies. Thus, the higher sensitivity of fetal intestinal tissue to inflammatory stimuli may induce labor due to an immune-mediated reaction. However, as mentioned previously, the presence of placental microbiota is under discussion due to methodological doubts, and these data have to be discussed with caution. 
Finally, a number of bacteria, viruses, and protozoa infections have been associated with pregnancy complications. Liu et al [95] analyzed the gut microbiome in pregnant women affected by preeclampsia. They showed an overall increase in pathogenic bacteria such as Clostridium perfringens and Bulleidia moorei and a reduction in probiotic bacteria Coprococcus catus. A correlation between periodontitis and the risk of spontaneous abortion or miscarriage has also been described [96]. More well-controlled studies should be carried out in order to identify interactions between pregnancy microbiome and mother and children health which might help to predict gestational and newborn complications and search for new therapeutic targets in adverse obstetrical conditions.

\section{Microbiome and Obese Pregnancy}

Epidemiological evidence shows that $50 \%$ of women in childbearing age and $20 \%-25 \%$ of pregnant women in Europe can be affected by overweight or obesity [97], increasing the cardiometabolic risk in mothers [98] and the susceptibility to metabolic diseases in offspring [99-102]. Pregnancy-associated changes are different in overweight or obese women compared to normal-weight pregnant women. Overweight pregnant women show a reduction in the number of Bifidobacterium and Bacteroides, and an increase in the number of Staphylococcus, Enterobacteriaceae, and Escherichia coli [11]. Additionally, higher levels of Staphylococcus and Akkermansia muciniphila, and lower levels of Bifidobacterium were detected in women with excessive weight gain during pregnancy as compared to normal-weight ones [76]. Consequently, this altered maternal microbiome will contribute to shape an altered composition of the offspring's microbiome $[103,104]$ and thus influence their future health.

Vaginal-born neonates from overweight or obese mothers show increased numbers of Bacteroides and depleted in Enterococcus, Acinetobacter, Pseudomonas, and Hydrogenophilus [104]. When specifically examining phyla level relative taxonomic abundance among preterm women by virtue of maternal weight gain, other authors have reported an appreciable and significant increased abundance of Firmicutes, Actinobacteria, and Cyanobacteria, and decreased relative abundance of Proteobacteria [92]. Furthermore, this altered maternal microbiota composition may be transferred from mother to fetus during the prenatal period [94] and through lactation [105].

In addition, gut microbiota can induce obesity in children by several mechanisms. For example, lower amounts of Bifidobacteria can affect weight gain in infants through mucosal host-microbe crosstalk, and immune and inflammatory dysregulation. Moreover, higher presence of Bacteroides, Clostridium, and Staphylococcus can stimulate greater energy extraction from food, combined with a reduced control of inflammation during the first six months of life in infants of overweight mothers [12]. These first months of life are of great importance since rapid weight gain during this period is associated with an increased risk of obesity during childhood, and this influence is even more important than the birth weight [106].

\section{Microbiome in Critical Ill Children}

Critical illness itself or its treatment can influence the composition of microbiota [107,108]. Although broad-spectrum antibiotics are probably the factor which further alters its composition, other factors can alter the ecosystem in which develops the microbiota, such as enteral or parenteral feeding, drugs administration, disease co-morbidities, central venous catheters, or intubation and mechanical ventilation. These studies have shown that the intestinal microbiota of critical patients has low diversity, with a shortage of key commensal bacteria and overgrowth of pathogenic bacteria such as Clostridium difficile, and some species of Enteococcus, Escherichia and Shigella [107,109-111]. In addition, the microbiota changes throughout the stay in the intensive care units (ICU) [112], and the possibility of pathogenic colonization increases with the time of stay in the unit.

To our best knowledge, only one study has analyzed the microbiota in children in a pediatric ICU (PICU) [113]. These authors found that the skin, oral, and fecal microbiota differs sharply from critically ill children compared with healthy children and adults. They reported a PICU-associated dysbiosis with less alpha-diversity, different composition (beta-diversity), and the loss of body site-specificity, 
increasing the abundance of nosocomial pathogens across all body sites and reducing gut commensals such as Faecalibacterium [113]. A number of studies have shown an association between the microbiota and the immune function [114], the systemic inflammation [115], the metabolism of nutrients [116], the function of the central nervous system [117], the circadian rhythm [118], and the digestive system [119]. Therefore, PICU-associated dysbiosis may contribute to malnutrition, nosocomial infection, neurocognitive alteration, organ dysfunction, and sepsis associated to critical illness [113], and may also have an effect on the lung, the brain, and the kidneys [107].

Critically ill patient conditions may contribute to changes in the oropharynx microbiota, such as the increase of Klebsiella or Pseudomonas proliferation. On one hand, sedation and endotracheal intubation decrease mucociliary clearance and cough, reducing the elimination of microorganisms. On the other hand, mechanical ventilation, pneumonia, and acute respiratory distress syndrome (ARDS) favor alveolar edema, increasing the amount of nutrients available and decreasing the amount of oxygen in some areas. These facts stimulate bacterial proliferation [120], and increase the risk of nosocomial infection and ARDS [121].

In addition to the critical patients, associated dysbiosis, hypoperfusion, and reperfusion of the intestinal wall produce an intense inflammation of the digestive mucosa which alters the gradient of oxygen concentration and increases the concentration of nitrates favoring the growth of pathogenic flora. Furthermore, the slowing down of intestinal transit, frequent drugs (sedatives, opioids, catecholamines), and the alteration of the mechanisms of microbial elimination (decreased production of bile salts and IgA, pharmacological alkalinization of $\mathrm{pH}$, etc.) may also influence the alteration of the digestive functions [122]. Freedberg et al. observed that colonization by some microorganisms prior to admission in ICU was associated with increased risk of infection by that same germ, and subsequently increased mortality [123]. This fact indicates that the gastrointestinal microbiome can help stratification and early identification of the risk of ICU patient complications.

\section{Microbiome and Sepsis in the Newborn}

The modification of the normal microbiota pattern can contribute to the development of a systemic inflammatory response with increased cytokine production, sepsis, multi-organ failure, and morbi-mortality [107,109-111]. In spite of variation in net incidence, neonatal sepsis remains one of the leading causes of preventable neonatal morbidity and mortality throughout the world. The main agents responsible for sepsis are group B Streptococcus (GBS), Escherichia coli, and coagulase-negative Staphylococci (CONS) [124]. However, this scenario may be modified depending on the use of antibiotics and/or the implementation of non-culture diagnostic techniques [125].

In recent years, there has been growing interest in the role of commensal bacteria in an individual's susceptibility to infection. A few studies have evaluated the maternal vaginal microbiota in relation to GBS carrier status. Although it seems that some specific taxa might be associated with the presence of GBS [126], there is no apparent parallel reduction of the predominant commensal bacteria Lactobacilli [127]. Indirect evidence suggests that the neonatal gut microbiome might be of relevance in GBS infection, since different colonizing species have been found in the stool of infants from GBS positive and negative mothers, while the protective effect of pre and probiotics has also been suggested [127].

It seems that gastrointestinal microbiota might induce an increase in permeability, modulating gut and systemic immune response, and decreasing the tight junction integrity [128]. As a consequence, intestinal bacteria can promote the systemic inflammatory response syndrome, facilitate bacterial translocation, and cause late-onset sepsis and necrotizing enterocolitis, especially affecting premature neonates. Most, but not all, of the evidence suggests that premature newborns with low microbiome gut diversity, or with predominance of Staphylococcus, Firmicutes, and Proteobacteria are associated with increased risk for late-onset sepsis compared to those premature infants at lower risk [129]. Furthermore, gut colonization with Bifidobacterium and increased presence of prebiotic oligosaccharides in feces, has been related to less disruption of the mucosal barrier and gut epithelial translocation, 
providing an improved gut development and protection [130]. It remains unclear if invasion of the bloodstream during sepsis is caused by the same microorganisms identified in stool [131] or by others [129], in which case the gut microbiota would act as a facilitating mechanism by interfering with the gut barrier or intestinal immune function. Further studies are needed to tease out if the differences observed in gut colonization in ICU patients predispose to sepsis or if they respond to other factors such as the diet, site differences in initiating and advancing feeds, breastfeeding, the use of antibiotics, or interpatient transmission within the neonatal intensive care units [131].

\section{Microbiome and Allergic Conditions}

Allergy disorders represent an important global health burden with an increasing prevalence in infants and children, mainly as food allergies, atopic eczema [132], and respiratory pathologies such as rhinitis [133] or asthma [134]. Their causes are multifactorial and contemplate interactions between genetic, environmental, and socioeconomic factors leading to different symptoms or phenotypes [135]. Among this heterogeneity, a restricted microbial exposure at early life seems to play an important role influencing allergic diseases, and asthma onset [136].

\subsection{Gut Microbiome and Atopy}

Eczema or atopic dermatitis (AD) is the first typical allergic manifestation in newborns [137]. A recent study has reported a high proportion of Faecalibacterium prausnitzii on the gut microbiome from AD subjects. The presence of these bacteria is lower in Crohn's disease patients, as well as anti-inflammatory fecal bacteria metabolites [138]. Besides, it has been shown that infants with AD improved their symptomatology when the abundance of fecal Coprococcus eutactus, a butyrate-producing bacterium, is increased [139]. Consequently, it has been proposed that dysbiotic gut microbiota and subsequent dysregulation of the gut inflammation may promote an aberrant Th2-type immune response to allergens altering the epithelial barrier in AD skin [140].

\subsection{Gut Microbiome and Food Allergy}

Available literature on animal models suggests that gut microbiome may have an important role in the susceptibility to food sensitization and food allergy, mainly at early stages of life [141]. Chen et al. [142] recently showed both lower microbiota alpha-diversity and altered gut microbiota composition (an increased number of Firmicutes in detriment of Bacteroidetes) in children with food sensitization in early life compared with children without these conditions. Among the causes, the increasing use of antibiotics both in humans and in agriculture, and the lower intake of dietary fiber may have an impact on these situations [143].

\subsection{Gut Microbiome and Asthma}

Allergies are the strongest risk factors for childhood asthma in Western countries [144], but the relationship between asthma and the microbiota is not clear. Although it seems that the diversity of the gut microbiota in infancy is even more determinant for asthma onset than the prevalence of specific bacterial taxa, it has been suggested that there might be specific important bacterial species related to the prevention of asthma, and that gut microbial diversity during the first month of life may be the most important factor associated with asthma development at school age than with other allergic manifestations [136]. In addition, another study has indicated that the neonatal gut microbiota influences susceptibility to childhood allergic asthma via alterations in the gut microenvironment that modulates CD4+ T-cell proliferation and functions. These authors have observed a characteristic depletion of dihomo- $\gamma$-linoleate, a precursor of anti-inflammatory $\omega-3$ polyunsaturated fatty acid and prostaglandins that may be related [145].

As described previously, different factors have been associated with infant microbiome and the risk of asthma, such as furry pets exposure [146], gestational age, the mode of delivery (vaginal vs. C-section), and antibiotic treatment (direct vs. indirect via mother) among others [147,148]. However, 
there is no doubt that a key issue is the type of feeding. A systematic review addressing the effect of breastfeeding in the development of asthma concluded that children who were breastfed for a longer time during the first two years of life had a lower risk of developing asthma, and this effect could be mediated by an adequate and early shaping of the gut microbiota $[149,150]$, although whether the dysbiotic microbiota is the cause or the consequence of atopic and allergic diseases is still unknown [140]. Besides, interventional studies have suggested that pre- and probiotics could prevent or down-regulate the severity of some diseases, such as asthma or allergies, but the biological mechanisms, as well as the best taxa or type of intervention, require further research [151].

\section{Microbiome and Infection in Infants}

The role of microbiome diversity and its variations in the incidence and susceptibility to infection has also aroused great interest beyond the neonatal period. In view of the interaction between the microbiota and the immune system, the implications are probably major and remain challenging, but for some authors, is even more attractive the idea of its usefulness as a diagnostic tool, a preventive strategy, or even a therapeutic target. As described in the neonatal period, in most infectious diseases scenarios, a decrease in alpha and beta diversity of the microbiota seems to be present. Regarding respiratory infections, diversity of the oropharyngeal and nasopharyngeal microbiota in children with pneumonia was lower compared with healthy controls. Furthermore, a correlation between the presence of certain taxa in sputum and the clinical course of community acquired pneumonia has been described [152,153].

HIV infected children present reduced gastrointestinal microbial diversity [154]. Modulation of the intestinal microbiome through nutritional supplementation, with the aim of decreasing bacterial permeability, has been attempted in the context of HIV infection with scarce success [155,156]. In addition, the microbiome has been suggested to impact the risk of different infectious diseases. Both vaginal and penile microbiotas modify the risk of sexual acquisition of HIV, due to their influence on inflammatory pathways and metabolization of antiretroviral drugs $[157,158]$. Recent studies have shown how an altered vaginal microbioma increases the risk of vertical transmission of HIV [159]. These studies beautifully exemplify the potential influence of the microbiome on the risk of infections, as well as its implications in pharmacokinetics modulating bacterial metabolism.

Finally, based on the potential role of the gut microbiota as a modulator of the immune function, attempts of supplementation with pre and probiotics have also been carried out. Two randomized controlled trials have analyzed the impact of probiotic supplementation on children with acute gastroenteritis without proving any beneficial clinical outcome [160,161]. Supplementation with prebiotics or probiotics may also enhance vaccine response and thus becomes a new tool for the improvement of vaccine efficacy [162]. However, results have been controversial in this field and warrant further investigation. The evidence for a beneficial effect of probiotics on vaccine response was strongest for oral vaccinations and for parenteral influenza vaccination, and depended on the choice of probiotic, strain, dose, viability, purity, and the time and duration of administration [163].

\section{Conclusions}

There are many data confirming the interaction of microbiota in pregnancy and in the newborn period, on the establishment of labor, children growth and development, and susceptibility to infections and diseases. However, most studies are descriptive and entangling factors influencing the human microbiome such as the age, race, type of feeding, mother's diet, and antibiotics treatments is challenging. Whatever it is, what is clear is that a number of microbiota-derived substances may easily reach the bloodstream, and impact human metabolism.

Recent advances in genome sequencing technologies, metabolomics, proteomics, transcriptomics, and bioinformatics will enable researchers to explore the fascinating field of the microbiota and, in particular, its functions at a more detailed level. Therefore, larger and prospective studies are needed to characterize the evolution of the microbiota during different conditions and its influence on healthy 
and pathological pregnancies, on labor onset, and on the perinatal period, in order to promote the development of new preventive, diagnostic, and therapeutic tools.

Author Contributions: All authors have contributed to the writing of the work. M.D.M. had primary responsibility for the final content. All authors have read and agreed to the published version of the manuscript.

Funding: This research was funded by the PN I+D+I 2008-2011 (Spain), ISCIII- Sub-Directorate General for Research Assessment and Promotion and the European Regional Development Fund (ERDF), RETICS Maternal and Child Health and Development Network, SAMID Network, Ref. RD16/0022/0015. Anna Parra-Llorca acknowledges Rio Hortega grant CM18/00165 from the Instituto de Investigación en Salud Carlos III (Ministry of Science, Universities and Innovation; Kingdom of Spain); Talía Sainz is funded by The Instituto de Salud Carlos III- Spanish Ministry of Science and Innovation cofounded by FEDER (EU). (Grant $\mathrm{n}^{\circ}$ JR16/00021); Cristina Calvo is a member of the IdiPAZ Research Institute, Madrid. Spain. Translational Research Network for Pediatric Infectious Diseases (RITIP), Madrid, Spain. TEDDY Network Member (European Network of Excellence for Pediatric Clinical Research, Bari, Italy).

Conflicts of Interest: The authors declare no conflict of interest.

\section{References}

1. Newbern, D.; Freemark, M. Placental hormones and the control of maternal metabolism and fetal growth. Curr. Opin. Endocrinol. Diabetes Obes. 2011, 18, 409-416. [CrossRef] [PubMed]

2. Rodríguez, J.M.; Murphy, K.; Stanton, C.; Ross, R.P.; Kober, O.; Juge, N.; Avershina, E.; Rudi, K.; Narbad, A.; Jenmalm, M.C.; et al. The composition of the gut microbiota throughout life, with an emphasis on early life. Microb. Ecol. Health Dis. 2015, 26, 26050. [CrossRef] [PubMed]

3. Jašarević, E.; Bale, T.L. Prenatal and postnatal contributions of the maternal microbiome on offspring programming. Front. Neuroendocrinol. 2019, 55, 100797. [CrossRef] [PubMed]

4. Koren, O.; Goodrich, J.K.; Cullender, T.C.; Spor, A.; Laitinen, K.; Bäckhed, H.K.; Gonzalez, A.; Werner, J.J.; Angenent, L.T.; Knight, R.; et al. Host remodeling of the gut microbiome and metabolic changes during pregnancy. Cell 2012, 150, 470-480. [CrossRef]

5. DiGiulio, D.B.; Callahan, B.J.; McMurdie, P.J.; Costello, E.K.; Lyell, D.J.; Robaczewska, A.; Sun, C.L.; Goltsman, D.S.; Wong, R.J.; Shaw, G.; et al. Temporal and spatial variation of the human microbiota during pregnancy. Proc. Natl. Acad. Sci. USA 2015, 112, 11060-11065. [CrossRef]

6. Peelen, M.J.; Luef, B.M.; Lamont, R.F.; de Milliano, I.; Jensen, J.S.; Limpens, J.; Hajenius, P.J.; Jørgensen, J.S.; Menon, R.; PREBIC Biomarker Working Group 2014-2018. The influence of the vaginal microbiota on preterm birth: A systematic review and recommendations for a minimum dataset for future research. Placenta 2019, 79, 30-39. [CrossRef]

7. Wankhade, U.D.; Zhong, Y.; Kang, P.; Alfaro, M.; Chintapalli, S.V.; Piccolo, B.D.; Mercer, K.E.; Andres, A.; Thakali, K.M.; Shankar, K. Maternal high-fat diet programs offspring liver steatosis in a sexually dimorphic manner in association with changes in gut microbial ecology in mice. Sci. Rep. 2018, 8, 16502. [CrossRef]

8. Olivier-Van Stichelen, S.; Rother, K.I.; Hanover, J.A. Maternal exposure to non-nutritive sweeteners impacts progeny's metabolism and microbiome. Front. Microbiol. 2019, 10, 1360. [CrossRef]

9. Garcia-Mantrana, I.; Selma-Royo, M.; Alcantara, C.; Collado, M.C. Shifts on Gut Microbiota Associated to Mediterranean Diet Adherence and Specific Dietary Intakes on General Adult Population. Front. Microbiol. 2018, 9, 890. [CrossRef]

10. Collado, M.C.; Isolauri, E.; Laitinen, K.; Salminen, S. Distinct composition of gut microbiota during pregnancy in overweight and normal-weight women. Am. J. Clin. Nutr. 2008, 88, 894-899. [CrossRef]

11. Santacruz, A.; Collado, M.C.; Garcia-Valdes, L.; Segura, M.T.; Martin-Lagos, J.A.; Anjos, T.; Martí-Romero, M.; Lopez, R.M.; Florido, J.; Campoy, C.; et al. Gut microbiota composition is associated with body weight, weight gain and biochemical parameters in pregnant women. Br. J. Nutr. 2010, 104, 83-92. [CrossRef] [PubMed]

12. Collado, M.C.; Isolauri, E.; Laitinen, K.; Salminen, S. Effect of mother's weight on infant's microbiota acquisition, composition, and activity during early infancy: A prospective follow-up study initiated in early pregnancy. Am. J. Clin. Nutr. 2010, 92, 1023-1230. [CrossRef] [PubMed]

13. Gomez-Arango, L.F.; Barrett, H.L.; McIntyre, H.D.; Callaway, L.K.; Morrison, M.; Dekker Nitert, M.; SPRING Trial Group. Connections Between the Gut Microbiome and Metabolic Hormones in Early Pregnancy in Overweight and Obese Women. Diabetes 2016, 65, 2214-2223. [CrossRef] [PubMed] 
14. Aagaard, K.; Riehle, K.; Ma, J.; Segata, N.; Mistretta, T.A.; Coarfa, C.; Raza, S.; Rosenbaum, S.; Van den Veyver, I.; Milosavljevic, A.; et al. A metagenomic approach to characterization of the vaginal microbiome signature in pregnancy. PLoS ONE 2012, 7, e36466. [CrossRef] [PubMed]

15. Aagaard, K.; Ma, J.; Antony, K.M.; Ganu, R.; Petrosino, J.; Versalovic, J. The placenta harbors a unique microbiome. Sci. Transl. Med. 2014, 21, 237ra65. [CrossRef] [PubMed]

16. Prince, A.L.; Ma, J.; Kannan, P.S.; Alvarez, M.; Gisslen, T.; Harris, R.A.; Sweeney, E.L.; Knox, C.L.; Lambers, D.S.; Jobe, A.H.; et al. The placental membrane microbiome is altered among subjects with spontaneous preterm birth with and without chorioamnionitis. Am. J. Obstet. Gynecol. 2016, 214, 627. [CrossRef]

17. Perez-Muñoz, M.E.; Arrieta, M.C.; Ramer-Tait, A.E.; Walter, J. A critical assessment of the "sterile womb" and "in utero colonization" hypotheses: Implications for research on the pioneer infant microbiome. Microbiome 2017, 28, 48. [CrossRef]

18. Guinane, C.M.; Cotter, P.D. Role of the gut microbiota in health and chronic gastrointestinal disease: Understanding a hidden metabolic organ. Therap. Adv. Gastroenterol. 2013, 6, 295-308. [CrossRef]

19. Smith, P.M.; Howitt, M.R.; Panikov, N.; Michaud, M.; Gallini, C.A.; Bohlooly, Y.M.; Glickman, J.N.; Garrett, W.S. The microbial metabolites, short-chain fatty acids, regulate colonic Treg cell homeostasis. Science 2013, 341, 569-573. [CrossRef]

20. Furusawa, Y.; Obata, Y.; Hase, K. Commensal microbiota regulates T cell fate decision in the gut. Semin. Immunopathol. 2015, 37, 17-25. [CrossRef]

21. Havstad, S.; Johnson, C.C.; Kim, H.; Levin, A.M.; Zoratti, E.M.; Joseph, C.L.; Ownby, D.R.; Wegienka, G. Atopic phenotypes identified with latent class analyses at age 2 years. J. Allergy Clin. Immunol. 2014, 134, 722-727. [CrossRef] [PubMed]

22. Lynch, S.V. Gut Microbiota and Allergic Disease. New Insights. Ann. Am. Thorac. Soc. 2016, 13 (Suppl. 1), S51-S54. [CrossRef] [PubMed]

23. Adak, A.; Khan, M.R. An insight into gut microbiota and its functionalities. Cell. Mol. Life Sci. 2019, 76, 473-493. [CrossRef] [PubMed]

24. Neuman, H.; Koren, O. The Pregnancy Microbiome. Nestle Nutr. Inst. Workshop Ser. 2017, 88, 1-9. [CrossRef]

25. Walters, W.A.; Xu, Z.; Knight, R. Meta-analyses of human gut microbes associated with obesity and IBD. FEBS Lett. 2014, 588, 4223-4233. [CrossRef]

26. Gosalbes, M.J.; Compte, J.; Moriano-Gutierrez, S.; Vallès, Y.; Jiménez-Hernández, N.; Pons, X.; Artacho, A.; Francino, M.P. Metabolic adaptation in the human gut microbiota during pregnancy and the first year of life. EBioMedicine 2019, 39, 497-509. [CrossRef]

27. Nyangahu, D.D.; Lennard, K.S.; Brown, B.P.; Darby, M.G.; Wendoh, J.M.; Havyarimana, E.; Smith, P.; Butcher, J.; Stintzi, A.; Mulder, N.; et al. Disruption of maternal gut microbiota during gestation alters offspring microbiota and immunity. Microbiome 2018, 6, 124. [CrossRef]

28. Nyangahu, D.D.; Jaspan, H.B. Influence of maternal microbiota during pregnancy on infant immunity. Clin. Exp. Immunol. 2019, 23. [CrossRef]

29. O'Hanlon, D.E.; Moench, T.R.; Cone, R.A. Vaginal $\mathrm{pH}$ and microbicidal lactic acid when lactobacilli dominate the microbiota. PLoS ONE 2013, 8, e80074. [CrossRef]

30. Smith, S.B.; Ravel, J. The vaginal microbiota, host defence and reproductive physiology. J. Physiol. 2017, 595, 451-463. [CrossRef]

31. Stoyancheva, G.; Marzotto, M.; Dellaglio, F.; Torriani, S. Bacteriocin production and gene sequencing analysis from vaginal Lactobacillus strains. Arch. Microbiol. 2014, 196, 645-653. [CrossRef] [PubMed]

32. Kroon, S.J.; Ravel, J.; Huston, W.M. Cervicovaginal microbiota, women's health, and reproductive outcomes. Fertil. Steril. 2018, 110, 327-336. [CrossRef] [PubMed]

33. Romero, R.; Hassan, S.S.; Gajer, P.; Tarca, A.L.; Fadrosh, D.W.; Nikita, L.; Galuppi, M.; Lamont, R.F.; Chaemsaithong, P.; Miranda, J.; et al. The composition and stability of the vaginal microbiota of normal pregnant women is different from that of non-pregnant women. Microbiome 2014, 2, 4. [CrossRef] [PubMed]

34. Stout, M.J.; Zhou, Y.; Wylie, K.M.; Tarr, P.I.; Macones, G.A.; Tuuli, M.G. Early pregnancy vaginal microbiome trends and preterm birth. Am. J. Obstet. Gynecol. 2017, 217, 356.e1-356.e18. [CrossRef]

35. Haque, M.M.; Merchant, M.; Kumar, P.N.; Dutta, A.; Mande, S.S. First-trimester vaginal microbiome diversity: A potential indicator of preterm delivery risk. Sci. Rep. 2017, 7, 16145. [CrossRef]

36. Lin, W.; Jiang, W.; Hu, X.; Gao, L.; Ai, D.; Pan, H.; Niu, C.; Yuan, K.; Zhou, X.; Xu, C.; et al. Ecological Shifts of Supragingival Microbiota in Association with Pregnancy. Front. Cell. Infect. Microbiol. 2018, 8, 24. [CrossRef] 
37. Fujiwara, N.; Tsuruda, K.; Iwamoto, Y.; Kato, F.; Odaki, T.; Yamane, N.; Hori, Y.; Harashima, Y.; Sakoda, A.; Tagaya, A.; et al. Significant increase of oral bacteria in the early pregnancy period in Japanese women. $J$. Investig. Clin. Dent. 2017, 8, 1. [CrossRef]

38. Kornman, K.S.; Loesche, W.J. Effects of estradiol and progesteroneon Bacteroides melaninogenicus and Bacteroides gingivalis. Infect. Immun. 1982, 35, 256-263.

39. Nuriel-Ohayon, M.; Neuman, H.; Koren, O. Microbial Changes during Pregnancy, Birth, and Infancy. Front. Microbiol. 2016, 7, 1031. [CrossRef]

40. Pelzer, E.; Gomez-Arango, L.F.; Barrett, H.L.; Nitert, M.D. Review: Maternal health and the placental microbiome. Placenta 2017, 54, 30-37. [CrossRef]

41. D'Argenio, V. The Prenatal Microbiome: A New Player for Human Health. High. Throughput 2018, 7, 38. [CrossRef] [PubMed]

42. Jimenez, E.; Fernandez, L.; Marin, M.L.; Martin, R.; Odriozola, J.M.; Nueno-Palop, C.; Narbad, A.; Olivares, M.; Xaus, J.; Rodríguez, J.M. Isolation of commensal bacteria from umbilical cord blood of healthy neonates born by C-section. Curr. Microbiol. 2005, 51, 270-274. [CrossRef] [PubMed]

43. Wassenaar, T.M.; Panigrahi, P. Is a foetus developing in a sterile environment? Lett. Appl. Microbiol. 2014, 59, 572-579. [CrossRef] [PubMed]

44. Collado, M.C.; Rautava, S.; Aakko, J.; Isolauri, E.; Salminen, S. Human gut colonisation may be initiated in utero by distinct microbial communities in the placenta and amniotic fluid. Sci. Rep. 2016, 22, 23129. [CrossRef] [PubMed]

45. DiGiulio, D.B.; Gervasi, M.; Romero, R.; Mazaki-Tovi, S.; Vaisbuch, E.; Kusanovic, J.P.; Seok, K.S.; Gómez, R.; Mittal, P.; Gotsch, F.; et al. Microbial invasion of the amniotic cavity in preeclampsia as assessed by cultivation and sequence-based methods. J. Perinat. Med. 2010, 38, 503-513. [CrossRef]

46. DiGiulio, D.B.; Romero, R.; Kusanovic, J.P.; Gómez, R.; Kim, C.J.; Seok, K.S.; Gotsch, F.; Mazaki-Tovi, S.; Vaisbuch, E.; Sanders, K.; et al. Prevalence and diversity of microbes in the amniotic fluid, the fetal inflammatory response, and pregnancy outcome in women with preterm pre-labor rupture of membranes. Am. J. Reprod. Immunol. 2010, 64, 38-57. [CrossRef]

47. Romero, R.; Miranda, J.; Chaemsaithong, P.; Chaiworapongsa, T.; Kusanovic, J.P.; Dong, Z.; Ahmed, A.I.; Shaman, M.; Lannaman, K.; Yoon, B.H.; et al. Sterile and microbial-associated intra-amniotic inflammation in preterm prelabor rupture of membranes. J. Matern.-Fetal Neonatal Med. 2015, 28, 1394-1409. [CrossRef]

48. McClure, E.M.; Goldenberg, R.L. Infection and stillbirth. Semin. Fetal Neonatal Med. 2009, 14, $182-189$. [CrossRef]

49. Fardini, Y.; Wang, X.; Témoin, S.; Nithianantham, S.; Lee, D.; Shoham, M.; Han, Y.W. Fusobacterium nucleatumadhesinFadA binds vascular endothelial cadherin and alters endothelial integrity. Mol. Microbiol. 2011, 82, 1468-1480. [CrossRef]

50. Franasiak, J.M.; Werner, M.D.; Juneau, C.R.; Tao, X.; Landis, J.; Zhan, Y.; Treff, N.R.; Scott, R.T. Endometrial microbiome at the time of embryo transfer: Next-generation sequencing of the $16 \mathrm{~S}$ ribosomal subunit. $J$. Assist. Reprod. Genet. 2016, 33, 129-136. [CrossRef]

51. Jimenez, E.; Marín, M.L.; Martín, R.; Odriozola, J.M.; Olivares, M.; Xaus, J.; Fernández, L.; Rodríguez, J.M. Is meconium from healthy newborns actually sterile? Res. Microbiol. 2008, 159, 187-193. [CrossRef] [PubMed]

52. Hansen, R.; Scott, K.P.; Khan, S.; Martin, J.C.; Berry, S.H.; Stevenson, M.; Okpapi, A.; Munro, M.J.; Hold, G.L. First-Pass Meconium Samples from Healthy Term Vaginally-Delivered Neonates: An Analysis of the Microbiota. PLoS ONE 2015, 10, e0133320. [CrossRef] [PubMed]

53. Martin, R.; Makino, H.; Cetinyurek Yavuz, A.; Ben-Amor, K.; Roelofs, M.; Ishikawa, E.; Kubota, H.; Swinkels, S.; Sakai, T.; Oishi, K.; et al. Early-Life Events, Including Mode of Delivery and Type of Feeding, Siblings and Gender, Shape the Developing Gut Microbiota. PLoS ONE 2016, 11, e0158498. [CrossRef] [PubMed]

54. Lauder, A.P.; Roche, A.M.; Sherrill-Mix, S.; Bailey, A.; Laughlin, A.L.; Bittinger, K.; Leite, R.; Elovitz, M.A.; Parry, S.; Bushman, F.D. Comparison of placenta samples with contamination controls does not provide evidence for a distinct placenta microbiota. Microbiome 2016, 23, 29. [CrossRef]

55. Rutayisire, E.; Huang, K.; Liu, Y.; Tao, F. The mode of delivery affects the diversity and colonization pattern of the gut microbiota during the first year of infants' life: A systematic review. BMC Gastroenterol. 2016, 16, 86. [CrossRef] 
56. Stinson, L.F.; Payne, M.S.; Keelan, J.A. A Critical Review of the Bacterial Baptism Hypothesis and the Impact of C-section Delivery on the Infant Microbiome. Front. Med. 2018, 4, 135. [CrossRef]

57. Montoya-Williams, D.; Lemas, D.J.; Spiryda, L.; Patel, K.; Carney, O.O.; Neu, J.; Carson, T.L. The Neonatal Microbiome and Its Partial Role in Mediating the Association between Birth by C-Section and Adverse Pediatric Outcomes. Neonatology 2018, 114, 103-111. [CrossRef]

58. Dominguez-Bello, M.G.; Costello, E.K.; Contreras, M.; Magris, M.; Hidalgo, G.; Fierer, N.; Knight, R. Delivery mode shapes the acquisition and structure of the initial microbiota across multiple body habitats in newborns. Proc. Natl. Acad. Sci. USA 2010, 107, 11971-11975. [CrossRef]

59. Biasucci, G.; Rubini, M.; Riboni, S.; Morelli, L.; Bessi, E.; Retetangos, C. Mode of delivery affects the bacterial community in the newborn gut. Early Hum. Dev. 2010, 86 (Suppl. 1), 13-15. [CrossRef]

60. Shi, Y.C.; Guo, H.; Chen, J.; Sun, G.; Ren, R.R.; Guo, M.Z.; Peng, L.H.; Yang, Y.S. Initial meconium microbiome in Chinese neonates delivered naturally or by C-section. Sci. Rep. 2018, 8, 3255. [CrossRef]

61. Backhed, F.; Roswall, J.; Peng, Y.; Feng, Q.; Jia, H.; Kovatcheva-Datchary, P.; Datchary, P.; Li, Y.; Xia, Y.; Xie, H.; et al. Dynamics and Stabilization of the Human Gut Microbiome during the First Year of Life. Cell Host. Microbe 2015, 17, 690-703. [CrossRef] [PubMed]

62. Sakwinska, O.; Foata, F.; Berger, B.; Brüssow, H.; Combremont, S.; Mercenier, A.; Dogra, S.; Soh, S.E.; Yen, J.C.K.; Heong, G.Y.S.; et al. Does the maternal vaginal microbiota play a role in seeding the microbiota of neonatal gut and nose? Benef. Microbes 2017, 8, 763-778. [CrossRef] [PubMed]

63. Escobar, J.S.; Klotz, B.; Valdes, B.E.; Agudelo, G.M. The gut microbiota of Colombians differs from that of Americans, Europeans and Asians. BMC Microbiol. 2014, 14, 311. [CrossRef] [PubMed]

64. Seedat, F.; Stinton, C.; Patterson, J.; Geppert, J.; Tan, B.; Robinson, E.R.; McCarthy, N.D.; Uthman, O.A.; Freeman, K.; Johnson, S.A.; et al. Adverse events in women and children who have received intrapartum antibiotic prophylaxis treatment: A systematic review. BMC Pregnancy Childbirth 2017, 17, 247. [CrossRef]

65. Azad, M.B.; Konya, T.; Maughan, H.; Guttman, D.S.; Field, C.J.; Chari, R.S.; Sears, M.R.; Becker, A.B.; Scott, J.A.; Kozyrskyj, A.L.; et al. Gut microbiota of healthy Canadian infants: Profiles by mode of delivery and infant diet at 4 months. CMAJ 2013, 185, 385-394. [CrossRef]

66. Martinez, K.A.; Devlin, J.C.; Lacher, C.R.; Yin, Y.; Cai, Y.; Wang, J.; Dominguez-Bello, M.G. Increased weight gain by C-section: Functional significance of the primordial microbiome. Sci. Adv. 2017, 3, eaao1874. [CrossRef]

67. Laubereau, B.; Filipiak-Pittroff, B.; von Berg, A.; Grübl, A.; Reinhardt, D.; Wichmann, H.E.; Koletzko, S.; GINI Study Group. C-section and gastrointestinal symptoms, atopic dermatitis, and sensitisation during the first year of life. Arch. Dis. Child. 2004, 89, 993-997. [CrossRef]

68. Negele, K.; Heinrich, J.; Borte, M.; von Berg, A.; Schaaf, B.; Lehmann, I.; Wichmann, H.E.; Bolte, G.; LISA Study Group. Mode of delivery and development of atopic disease during the first 2 years of life. Pediatr. Allergy Immunol. 2004, 15, 48-54. [CrossRef]

69. Cabrera-Rubio, R.; Mira-Pascual, L.; Mira, A.; Collado, M.C. Impact of mode of delivery on the milk microbiota composition of healthy women. J. Dev. Orig. Health. Dis. 2016, 7, 54-60. [CrossRef]

70. Toscano, M.; De Grandi, R.; Peroni, D.G.; Grossi, E.; Facchin, V.; Comberiati, P.; Drago, L. Impact of delivery mode on the colostrum microbiota composition. BMC Microbiol. 2017, 17, 205. [CrossRef]

71. Neu, J.; Rushing, J. C-section versus vaginal delivery: Long-term infant outcomes and the hygiene hypothesis. Clin. Perinatol. 2011, 38, 321-331. [CrossRef] [PubMed]

72. Moya-Perez, A.; Luczynski, P.; Renes, I.B.; Wang, S.; Borre, Y.; Anthony Ryan, C.; Knol, J.; Stanton, C.; Dinan, T.G.; Cryan, J.F. Intervention strategies for cesarean section-induced alterations in the microbiota-gut-brain axis. Nutr. Rev. 2017, 75, 225-240. [CrossRef] [PubMed]

73. Francavilla, R.; Cristofori, F.; Tripaldi, M.E.; Indrio, F. Intervention for Dysbiosis in Children Born by C-Section. Ann. Nutr. Metab. 2018, 73 (Suppl. 3), 33-39. [CrossRef]

74. Penders, J.; Thijs, C.; Vink, C.; Stelma, F.F.; Snijders, B.; Kummeling, I.; van den Brandt, P.A.; Stobberingh, E.E. Factors influencing the composition of the intestinal microbiota in early infancy. Pediatrics 2006, 118, 511-521. [CrossRef] [PubMed]

75. Clarke, G.; O'Mahony, S.M.; Dinan, T.G.; Cryan, J.F. Priming for health: Gut microbiota acquired in early life regulates physiology, brain and behaviour. Acta Paediatr. 2014, 103, 812-819. [CrossRef]

76. Collado, M.C.; Laitinen, K.; Salminen, S.; Isolauri, E. Maternal weight and excessive weight gain during pregnancy modify the immunomodulatory potential of breast milk. Pediatr. Res. 2012, 72, 77-85. [CrossRef] 
77. American Academy of Pediatrics. Breastfeeding and the use of human milk. Pediatrics 2012, 129, e827-e884. [CrossRef]

78. Belfort, M.B.; Anderson, P.J.; Nowak, V.A.; Lee, K.J.; Molesworth, C.; Thompson, D.K.; Doyle, L.W.; Inder, T.E. Breast milk feeding, brain development, and neurocognitive outcomes: A 7-year longitudinal study in infants born at less than 30 weeks' gestation. J. Pediatr. 2016, 177, 133-139. [CrossRef]

79. Meinzen-Derr, J.; Poindexter, B.; Wrage, L.; Morrow, A.L.; Stoll, B.; Donovan, E.F. Role of human milk in extremely low birth weight infants' risk of necrotizing enterocolitis or death. J. Perinatol. 2009, 29, 57-62. [CrossRef]

80. Ballard, O.; Morrow, A.L. Human milk composition: Nutrients and bioactive factors. Pediatr. Clin. N. Am. 2013, 60, 49-74. [CrossRef]

81. Parra-Llorca, A.; Gormaz, M.; Alcantara, C.; Cernada, M.; Nuñez-Ramiro, A.; Vento, M.; Collado, M.C. Preterm Gut Microbiome Depending on Feeding Type: Significance of Donor Human Milk. Front. Microbiol. 2018, 27, 1376. [CrossRef] [PubMed]

82. Vento, M.; Hummler, H.; Dawson, J.A.; Escobar, J.; Kuligowski, J. Use of Oxygen in the Resuscitation of Neonates. In Perinatal and Prenatal Disorders; Dennery, P.A., Buonocore, G., Saugstad, O.D., Eds.; Humana Press: New York, NY, USA, 2014; pp. 213-244.

83. Parra-Llorca, A.; Gormaz, M.; Sánchez-Illana, A.; Piñeiro-Ramos, J.D.; Collado, M.C.; Serna, E.; Cernada, M.; Nuñez-Ramiro, A.; Ramón-Beltrán, A.; Oger, C.; et al. Does pasteurized donor human milk efficiently protect preterm infants against oxidative stress? Antioxid. Redox Signal. 2019, 31, 791-799. [CrossRef] [PubMed]

84. Parra-Llorca, A.; Gormaz, M.; Lorente-Pozo, S.; Cernada, M.; García-Robles, A.; Torres-Cuevas, I.; Kuligowski, J.; Collado, M.C.; Serna, E.; Vento, M. Impact of donor human milk in the preterm very low birth weight gut transcriptome profile by use of exfoliated intestinal cells. Nutrients 2019, 11, 2677. [CrossRef]

85. Bertino, E.; Giuliani, F.; Occhi, L.; Coscia, A.; Tonetto, P.; Marchino, F.; Fabris, C. Benefits of donor human milk for preterm infants: Current evidence. Early Hum. Dev. 2009, 85, S9-S10. [CrossRef] [PubMed]

86. Christen, L.; Lai, C.T.; Hartmann, B.; Hartmann, P.E.; Geddes, D.T. The effect of UV-C pasteurization on bacteriostatic properties and immunological proteins of donor human milk. PLoS ONE 2013, 8, e85867. [CrossRef] [PubMed]

87. Madore, L.S.; Bora, S.; Erdei, C.; Jumani, T.; Dengos, A.R.; Sen, S. Effects of donor breastmilk feeding on growth and early neurodevelopmental outcomes in preterm infants: An observational study. Clin. Ther. 2017, 39, 1210-1220. [CrossRef]

88. Untalan, P.B.; Keeney, S.E.; Palkowetz, K.H.; Rivera, A.; Goldman, S. Heat susceptibility of interleukin-10 and other cytokines in donor human milk. Breastfeed. Med. 2009, 4, 137-144. [CrossRef]

89. Sousa, S.G.; Santos, M.D.; Fidalgo, L.G.; Delgadillo, I.; Saraiva, J.A. Effect of thermal pasteurisation and high-pressure processing on immunoglobulin content and lysozyme and lactoperoxidase activity in human colostrum. Food Chem. 2014, 151, 79-85. [CrossRef]

90. Peila, C.; Moro, G.E.; Bertino, E.; Cavallarin, L.; Giribaldi, M.; Giuliani, F.; Cresi, F.; Coscia, A. The effect of holder pasteurization on nutrients and biologically-active components in donor human milk: A review. Nutrients 2016, 8, 477. [CrossRef]

91. Ardissone, A.N.; De La Cruz, D.M.; Davis-Richardson, A.G.; Rechcigl, K.T.; Li, N.; Drew, J.C.; Murgas-Torrazza, R.; Sharma, R.; Hudak, M.L.; Triplett, E.W.; et al. Meconium microbiome analysis identifies bacteria correlated with premature birth. PLoS ONE 2014, 9, e90784. [CrossRef]

92. Antony, K.M.; Ma, J.; Mitchell, K.B.; Racusin, D.A.; Versalovic, J.; Aagaard, K. The preterm placental microbiome varies in association with excess maternal gestational weight gain. Am. J. Obstet. Gynecol. 2015, 212, 653.e1-653.e16. [CrossRef] [PubMed]

93. Ejtahed, H.S.; Mohtadi-Nia, J.; Homayouni-Rad, A.; Niafar, M.; Asghari-Jafarabadi, M.; Mofid, V. Probiotic yogurt improves antioxidant status in type 2 diabetic patients. Nutrition 2012, 28, 539-543. [CrossRef] [PubMed]

94. Zheng, J.; Xiao, X.; Zhang, Q.; Mao, L.; Yu, M.; Xu, J. The placental microbiome varies in association with low birth weight in full-term neonates. Nutrients 2015, 7, 6924-6937. [CrossRef] [PubMed]

95. Liu, J.; Yang, H.; Yin, Z.; Jiang, X.; Zhong, H.; Qiu, D.; Zhu, F.; Li, R. Remodeling of the gut microbiota and structural shifts in Preeclampsia patients in South China. Eur. J. Clin. Microbiol. Infect. Dis. 2017, 36, 713-719. [CrossRef] 
96. Chanomethaporn, A.; Chayasadom, A.; Wara-Aswapati, N.; Kongwattanakul, K.; Suwannarong, W.; Tangwanichgapong, K.; Sumanonta, G.; Matangkasombut, O.; Dasanayake, A.P.; Pitiphat, W. Association between periodontitis and spontaneous abortion: A case-control study. J. Periodontol. 2019, 90, 381-390. [CrossRef]

97. Stevens, G.A.; Singh, G.M.; Lu, Y.; Danaei, G.; Lin, J.K.; Finucane, M.M.; Bahalim, A.N.; McIntire, R.K.; Gutierrez, H.R.; Cowan, M.; et al. National, regional, and global trends in adult overweight and obesity prevalences. Popul. Health Metr. 2012, 10, 22. [CrossRef]

98. Zhu, Y.; Zhang, C. Prevalence of Gestational Diabetes and Risk of Progression to Type 2 Diabetes: A Global Perspective. Curr. Diabates Rep. 2016, 16, 7. [CrossRef]

99. Eriksson, J.G.; Sandboge, S.; Salonen, M.; Kajantie, E.; Osmond, C. Maternal weight in pregnancy and offspring body composition in late adulthood: Findings from the Helsinki Birth Cohort Study (HBCS). Ann. Med. 2015, 47, 94-99. [CrossRef]

100. Hussen, H.I.; Persson, M.; Moradi, T. Maternal overweight and obesity are associated with increased risk of type 1 diabetes in offspring of parents without diabetes regardless of ethnicity. Diabetologia 2015, 58, 1464-1473. [CrossRef]

101. Gaillard, R.; Santos, S.; Duijts, L.; Felix, J.F. Childhood Health Consequences of Maternal Obesity during Pregnancy: A Narrative Review. Ann. Nutr. Metab. 2016, 69, 171-180. [CrossRef]

102. Toemen, L.; Gishti, O.; van Osch-Gevers, L.; Steegers, E.A.; Helbing, W.A.; Felix, J.F.; Reiss, I.K.; Duijts, L.; Gaillard, R.; Jaddoe, V.W. Maternal obesity, gestational weight gain and childhood cardiac outcomes: Role of childhood body mass index. Int. J. Obes. 2016, 40, 1070-1078. [CrossRef] [PubMed]

103. Ma, J.; Prince, A.L.; Bader, D.; Hu, M.; Ganu, R.; Baquero, K.; Blundell, P.; Alan Harris, R.; Frias, A.E.; Grove, K.L.; et al. High-fat maternal diet during pregnancy persistently alters the offspring microbiome in a primate model. Nat. Commun. 2014, 20, 3889. [CrossRef] [PubMed]

104. Mueller, N.T.; Shin, H.; Pizoni, A.; Werlang, I.C.; Matte, U.; Goldani, M.Z.; Goldani, H.A.; Dominguez-Bello, M.G. Birth mode-dependent association between pre-pregnancy maternal weight status and the neonatal intestinal microbiome. Sci. Rep. 2016, 1, 23133. [CrossRef] [PubMed]

105. Garcia-Mantrana, I.; Collado, M.C. Obesity and overweight: Impact on maternal and milk microbiome and their role for infant health and nutrition. Mol. Nutr. Food Res. 2016, 60, 865-875. [CrossRef] [PubMed]

106. Taveras, E.M.; Rifas-Shiman, S.L.; Belfort, M.B.; Kleinman, K.P.; Oken, E.; Gillman, M.W. Weight status in the first 6 months of life and obesity at 3 years of age. Pediatrics 2009, 123, 1177-1183. [CrossRef]

107. Jacobs, M.C.; Haak, B.W.; Hugenholtz, F.; Wiersinga, W.J. Gut microbiota and host defense in critical illness. Curr. Opin. Crit. Care 2017, 23, 257-263. [CrossRef]

108. Williams, V.; Angurana, S.K. Probiotics do have a role to play in treating critically ill children. Acta Paediatr. 2019, 108, 180. [CrossRef]

109. Kitsios, G.D.; Morowitz, M.J.; Dickson, R.P.; Huffnagle, G.B.; McVerry, B.J.; Morris, A. Dysbiosis in the intensive care unit: Microbiome science coming to the bedside. J. Crit. Care 2017, 38, 84-91. [CrossRef]

110. Lyons, J.D.; Coopersmith, C.M. Pathophysiology of the Gut and the Microbiome in the Host Response. Pediatr. Crit. Care Med. 2017, 18, S46-S49. [CrossRef]

111. Wischmeyer, P.E.; McDonald, D.; Knight, R. Role of the microbiome, probiotics, and 'dysbiosis therapy' in critical illness. Curr. Opin. Crit. Care 2016, 22, 347-353. [CrossRef]

112. Lankelma, J.M.; van Vught, L.A.; Belzer, C.; Schultz, M.J.; van der Poll, T.; de Vos, W.M.; Wiersinga, W.J. Critically ill patients demonstrate large interpersonal variation in intestinal microbiota dysregulation: A pilot study. Intensive Care Med. 2017, 43, 59-68. [CrossRef] [PubMed]

113. Rogers, M.B.; Firek, B.; Shi, M.; Yeh, A.; Brower-Sinning, R.; Aveson, V.; Kohl, B.L.; Fabio, A.; Carcillo, J.A.; Morowitz, M.J. Disruption of the microbiota across multiple body sites in critically ill children. Microbiome 2016, 4, 66. [CrossRef] [PubMed]

114. Surana, N.K.; Kasper, D.L. Deciphering the tête-à-tête between the microbiota and the immune system. J. Clin. Investig. 2014, 124, 4197-4203. [CrossRef]

115. Trompette, A.; Gollwitzer, E.S.; Yadava, K.; Sichelstiel, A.K.; Sprenger, N.; Ngom-Bru, C.; Blanchard, C.; Junt, T.; Nicod, L.P.; Harris, N.L.; et al. Gut microbiota metabolism of dietary fiber influences allergic airway disease and hematopoiesis. Nat. Med. 2014, 20, 159-166. [CrossRef] [PubMed]

116. Tremaroli, V.; Bäckhed, F. Functional interactions between the gut microbiota and host metabolism. Nature 2012, 489, 242-249. [CrossRef] [PubMed] 
117. Mayer, E.A.; Tillisch, K.; Gupta, A. Gut/brain axis and the microbiota. J. Clin. Investig. 2015, 2, $926-938$. [CrossRef]

118. Leone, V.; Gibbons, S.M.; Martinez, K.; Hutchison, A.L.; Huang, E.Y.; Cham, C.M.; Pierre, J.F.; Heneghan, A.F.; Nadimpalli, A.; Hubert, N.; et al. Effects of diurnal variation of gut microbes and high-fat feeding on host circadian clock function and metabolism. Cell Host Microbe 2015, 13, 681-689. [CrossRef]

119. Wolff, N.S.; Hugenholtz, F.; Wiersinga, W.J. The emerging role of the microbiota in the ICU. Crit. Care 2018, 22, 78. [CrossRef]

120. Rajilić-Stojanović, M.; de Vos, W.M. The first 1000 cultured species of the human gastrointestinal microbiota. FEMS Microbiol. Rev. 2014, 38, 996-1047. [CrossRef]

121. Haaka, B.W.; Levi, M.; Wiersinga, W.J. Microbiota-targeted therapies on the intensive care unit. Curr. Opin. Crit. Care 2017, 23, 167-174. [CrossRef]

122. Dickson, R.P. The microbiome and critical illness. Lancet Respir. Med. 2016, 4, 59-72. [CrossRef]

123. Freedberg, D.E.; Zhou, M.J.; Cohen, M.E.; Annavajhala, M.K.; Khan, S.; Moscoso, D.I.; Brooks, C.; Whittier, S.; Chong, D.H.; Uhlemann, A.C.; et al. Pathogen colonization of the gastrointestinal microbiome at intensive care unit admission and risk for subsequent death or infection. Intensive Care Med. 2018, 44, 1203-1211. [CrossRef] [PubMed]

124. Shane, A.L.; Stoll, B.J. Recent developments and current issues in the epidemiology, diagnosis, and management of bacterial and fungal neonatal sepsis. Am. J. Perinatol. 2013, 30, 131-141. [CrossRef] [PubMed]

125. Özenci, V.; Schubert, U. Earlier and more targeted treatment of neonatal sepsis. Acta Paediatr. 2018, 108, 169-170. [CrossRef]

126. Rosen, G.H.; Randis, T.M.; Desai, P.V.; Sapra, K.J.; Ma, B.; Gajer, P.; Humphrys, M.S.; Ravel, J.; Gelbe, S.E.; Ratner, A.J. Group B Streptococcus and the vaginal microbiota. J. Infect. Dis. 2017, 16, 744-751. [CrossRef]

127. Kolter, J.; Henneke, P. Codevelopment of microbiota and innate immunity and the risk for Group B Streptococcal disease. Front. Immunol. 2017, 8, 1497. [CrossRef]

128. Berrington, J.E.; Stewart, C.J.; Embleton, N.D.; Cummings, S.P. Gut microbiota in preterm infants: Assessment and relevance to health and disease. Arch. Dis. Child.-Fetal Neonatal Ed. 2013, 98, F286-F290. [CrossRef]

129. Madan, J.C.; Salari, R.C.; Saxena, D.; Davidson, L.; O’Toole, G.A.; Moore, J.H.; Sogin, M.L.; Foster, J.A.; Edwards, W.H.; Palumbo, P.; et al. Gut microbial colonisation in premature neonates predicts neonatal sepsis. Arch. Dis. Child.-Fetal Neonatal Ed. 2012, 97, F456-F462. [CrossRef]

130. Stewart, C.J.; Embleton, N.D.; Marrs, E.C.L.; Smith, D.P.; Fofanova, T.; Nelson, A. Longitudinal development of the gut microbiome and metabolome in preterm neonates with late onset sepsis and healthy controls. Microbiome 2017, 5, 75. [CrossRef]

131. Carl, M.A.; Ndao, I.M.; Springman, A.C.; Manning, S.D.; Johnson, J.R.; Johnston, B.D.; Burnham, C.A.D.; Weinstock, E.S.; Weinstock, G.M.; Wylie, T.N.; et al. Sepsis from the gut: The enteric habitat of bacteria that cause late-onset neonatal bloodstream infections. Clin. Infect. Dis. 2014, 58, 1211-1218. [CrossRef]

132. Dunlop, J.H.; Keet, C.A. Epidemiology of Food Allergy. Immunol. Allergy. Clin. N. Am. 2018, 38, 13-25. [CrossRef] [PubMed]

133. Bousquet, J.; Khaltaev, N.; Cruz, A.A.; Denburg, J.; Fokkens, W.J.; Togias, A.; Burnham, C.A.; Weinstock, E.S.; Weinstock, G.M.; Wylie, T.N.; et al. Allergic Rhinitis and its Impact on Asthma (ARIA) 2008 update (in collaboration with the World Health Organization, GA(2)LEN and AllerGen). Allergy 2008, 63 (Suppl. 86), 8-160. [CrossRef] [PubMed]

134. Bousquet, J.; Kaltaev, N.; World Health Organization. Global Surveillance, Prevention and Control of Chronic Respiratory Diseases: A Comprehensive Approach. Global Alliance against Chronic Respiratory Diseases: 2007. Available online: http://www.who.int/iris/handle/10665/43776 (accessed on 2 August 2019).

135. Johansson, S.G.; Bieber, T.; Dahl, R.; Friedmann, P.S.; Lanier, B.Q.; Lockey, R.F.; Motala, C.; Ortega Martell, J.A.; Platts-Mills, T.A.; Ring, J.; et al. Revised nomenclature for allergy for global use: Report of the Nomenclature Review Committee of the World Allergy Organization, October 2003. Allergy Clin. Immunol. 2004, 113, 832-836. [CrossRef] [PubMed]

136. Abrahamsson, T.R.; Jakobsson, H.E.; Andersson, A.F.; Bjorksten, B.; Engstrand, L.; Jenmalm, M.C. Low gut microbiota diversity in early infancy precedes asthma at school age. Clin. Exp. Allergy 2013, 44, 842-850. [CrossRef] 
137. Wopereis, H.; Sim, K.; Shaw, A.; Warner, J.O.; Knol, J.; Kroll, J.S. Intestinal microbiota in infants at high risk for allergy: Effects of prebiotics and role in eczema development. J. Allergy Clin. Immunol. 2017, 141, 1334-1342. [CrossRef]

138. Song, H.; Yoo, Y.; Hwang, J.; Na, Y.C.; Kim, H.S. Faecalibacterium prausnitzii subspecies-level dysbiosis in the human gut microbiome underlying atopic dermatitis. J. Allergy Clin. Immunol. 2015, 137, 852-860. [CrossRef]

139. Nylund, L.; Nermes, M.; Isolauri, E.; Salminen, S.; de Vos, W.M.; Satokari, R. Severity of atopic disease inversely correlates with intestinal microbiota diversity and butyrate-producing bacteria. Allergy 2015, 70, 241-244. [CrossRef]

140. Muir, A.B.; Benitez, A.J.; Dods, K.; Spergel, J.M.; Fillon, S.A. Microbiome and its impact on gastrointestinal atopy. Allergy 2016, 71, 1256-1263. [CrossRef]

141. Stefka, A.T.; Feehley, T.; Tripathi, P.; Qiu, J.; McCoy, K.; Mazmanian, S.K.; Tjota, M.Y.; Seo, G.Y.; Cao, S.; Theriault, B.R.; et al. Commensal bacteria protect against food allergen sensitization. Proc. Natl. Acad. Sci. USA 2014, 111, 13145-13150. [CrossRef]

142. Chen, C.C.; Chen, K.J.; Kong, M.S.; Chang, H.J.; Huang, J.L. Alterations in the gut microbiotas of children with food sensitization in early life. Pediatr. Allergy Immunol. 2015, 27, 254-262. [CrossRef]

143. Berni Canani, R.; Gilbert, J.A.; Nagler, C.R. The role of the commensal microbiota in the regulation of tolerance to dietary allergens. Curr. Opin. Allergy Clin. Immunol. 2015, 15, 243-249. [CrossRef] [PubMed]

144. Simpson, A.; Tan, V.Y.; Winn, J.; Svensen, M.; Bishop, C.M.; Heckerman, D.E.; Buchan, I.; Custovic, A. Beyond atopy: Multiple patterns of sensitization in relation to asthma in a birth cohort study. Am. J. Respir. Crit. Care Med. 2010, 181, 1200-1206. [CrossRef] [PubMed]

145. Fujimura, K.E.; Sitarik, A.R.; Havstad, S.; Lin, D.L.; Levan, S.; Fadrosh, D.; Panzer, A.R.; LaMere, B.; Rackaityte, E.; Lukacs, N.W.; et al. Neonatal gut microbiota associates with childhood multisensitized atopy and T cell differentiation. Nat. Med. 2016, 22, 1187-1191. [CrossRef] [PubMed]

146. Tun, H.M.; Konya, T.; Takaro, T.K.; Brook, J.R.; Chari, R.; Field, C.J.; Guttman, D.S.; Becker, A.B.; Mandhane, P.J.; Turvey, S.E.; et al. Exposure to household furry pets influences the gut microbiota of infant at 3-4 months following various birth scenarios. Microbiome 2017, 5, 40. [CrossRef] [PubMed]

147. Marques, T.M.; Wall, R.; Ross, R.P.; Fitzgerald, G.F.; Ryan, C.A.; Stanton, C. Programming infant gut microbiota: Influence of dietary and environmental factors. Curr. Opin. Biotechnol. 2010, 21, 149-156. [CrossRef]

148. Chong, C.Y.L.; Bloomfield, F.H.; O'Sullivan, J.M. Factors Affecting Gastrointestinal Microbiome Development in Neonates. Nutrients 2018, 10, 274. [CrossRef]

149. Dogaru, C.M.; Nyffenegger, D.; Pescatore, A.M.; Spycher, B.D.; Kuehni, C.E. Breastfeeding and childhood asthma: Systematic review and meta-analysis. Am. J. Epidemiol. 2014, 179, 1153-1167. [CrossRef]

150. Groer, M.W.; Luciano, A.A.; Dishaw, L.J.; Ashmeade, T.L.; Miller, E.; Gilbert, J.A. Development of the preterm infant gut microbiome: A research priority. Microbiome 2014, 2, 38. [CrossRef]

151. Mennini, M.; Dahdah, L.; Artesani, M.C.; Fiocchi, A.; Martelli, A. Probiotics in Asthma and Allergy Prevention. Front. Pediatr. 2017, 5, 165. [CrossRef]

152. Sakwinska, O.; Bastic Schmid, V.; Berger, B.; Bruttin, A.; Keitel, K.; Lepage, M.; Moine, D.; Ngom Bru, C.; Brüssow, H.; Gervaix, A. Nasopharyngeal microbiota in healthy children and pneumonia patients. J. Clin. Microbiol. 2014, 52, 1590-1594. [CrossRef]

153. Pettigrew, M.M.; Gent, J.F.; Kong, Y.; Wade, M.; Gansebom, S.; Bramley, A.M.; Jain, S.; Arnold, S.L.; McCullers, J.A. Association of sputum microbiota profiles with severity of community-acquired pneumonia in children. BMC Infect. Dis. 2016, 8, 317. [CrossRef] [PubMed]

154. Machiavelli, A.; Duarte, R.T.D.; Pires, M.M.S.; Zárate-Bladés, C.R.; Pinto, A.R. The impact of in utero HIV exposure on gut microbiota, inflammation, and microbial translocation. Gut Microbes 2019, 10, 599-614. [CrossRef]

155. Kaur, U.S.; Shet, A.; Rajnala, N.; Gopalan, B.P.; Moar, P.D.H.; Singh, B.P.; Chaturvedi, R.; Tandon, R. High Abundance of genus Prevotella in the gut of perinatally HIV-infected children is associated with IP-10 levels despite therapy. Sci. Rep. 2018, 5, 17679. [CrossRef] [PubMed] 
156. Serrano-Villar, S.; de Lagarde, M.; Vázquez-Castellanos, J.; Vallejo, A.; Bernadino, J.I.; Madrid, N.; Matarranz, M.; Díaz-Santiago, A.; Gutiérrez, C.; Cabello, A.; et al. Effects of Immunonutrition in Advanced Human Immunodeficiency Virus Disease: A Randomized Placebo-controlled Clinical Trial [Promaltia Study]. Clin. Infect. Dis. 2019, 1, 120-130. [CrossRef] [PubMed]

157. Liu, C.M.; Prodger, J.L.; Tobian, A.A.R.; Abraham, A.G.; Kigozi, G.; Hungate, B.A.; Aziz, M.; Nalugoda, F.; Sariya, S.; Serwadda, D.; et al. Penile Anaerobic Dysbiosis as a Risk Factor for HIV Infection. MBio 2017, 25, 8. [CrossRef]

158. Klatt, N.R.; Cheu, R.; Birse, K.; Zevin, A.S.; Perner, M.; Noël-Romas, L.; Grobler, A.; Westmacott, G.; Xie, I.Y.; Butler, J.; et al. Vaginal bacteria modify HIV tenofovir microbicide efficacy in African women. Science 2017, 2, 938-945. [CrossRef]

159. Frank, D.N.; Manigart, O.; Leroy, V.; Meda, N.; Valéa, D.; Zhang, W.; Dabis, F.; Pace, N.R.; Van de Perre, P.; Janoff, E. Altered vaginal microbiota are associated with perinatal mother-to-child transmission of HIV in African women from Burkina Faso. J. Acquir. Immune Defic. Syndr. 2012, 1, 299-306. [CrossRef]

160. Freedman, S.B.; Williamson-Urquhart, S.; Farion, K.J.; Gouin, S.; Willan, A.R.; Poonai, N.; Hurley, K.; Sherman, P.M.; Finkelstein, Y.; Lee, B.E.; et al. Multicenter Trial of a Combination Probiotic for Children with Gastroenteritis. N. Engl. J. Med. 2018, 22, 2015-2026. [CrossRef]

161. Schnadower, D.; Tarr, P.I.; Casper, T.C.; Gorelick, M.H.; Dean, J.M.; O’Connell, K.J.; Mahajan, P.; Levine, A.C.; Bhatt, S.R.; Roskind, C.G.; et al. Lactobacillus rhamnosus GG versus Placebo for Acute Gastroenteritis in Children. N. Engl. J. Med. 2018, 22, 2002-2014. [CrossRef]

162. Yeh, T.L.; Shih, P.C.; Liu, S.J.; Lin, C.H.; Liu, J.M.; Lei, W.T.; Lin, C.Y. The influence of prebiotic or probiotic supplementation on antibody titers after influenza vaccination: A systematic review and meta-analysis of randomized controlled trials. Drug Des. Dev. Ther. 2018, 25, 217-230. [CrossRef]

163. Zimmermann, P.; Curtis, N. The influence of probiotics on vaccine responses-A systematic review. Vaccine 2018, 4, 207-213. [CrossRef] [PubMed]

(C) 2020 by the authors. Licensee MDPI, Basel, Switzerland. This article is an open access article distributed under the terms and conditions of the Creative Commons Attribution (CC BY) license (http://creativecommons.org/licenses/by/4.0/). 